\title{
Microstructure and Corrosion Behavior of the As-Extruded Mg-4Zn-2Gd-0.5Ca Alloy
}

\author{
Hao-Yi Niu ${ }^{1}$ Fang-Fang Cao ${ }^{1} \cdot$ Kun-Kun Deng ${ }^{1} \cdot \mathrm{Kai}^{-B o} \mathrm{Nie}^{1} \cdot$ Jin-Wen Kang ${ }^{1} \cdot \mathrm{Hong}^{-W e i}$ Wang $^{1}$
}

Received: 29 August 2019/ Revised: 11 October 2019/ Published online: 19 December 2019

(C) The Chinese Society for Metals (CSM) and Springer-Verlag GmbH Germany, part of Springer Nature 2019

\begin{abstract}
In order to study the corrosion resistance of extruded magnesium alloys, the $\mathrm{Mg}-4 \mathrm{Zn}-2 \mathrm{Gd}-0.5 \mathrm{Ca}$ alloy was extruded at the speed of $0.01-0.1 \mathrm{~mm} / \mathrm{s}$ with the temperature of $280-360{ }^{\circ} \mathrm{C}$ in present study. Hot extrusion results show that the volume fraction of precipitates $\left(V_{\mathrm{pre}}\right), V_{\mathrm{DRX}}$ (the dynamic recrystallization rate) and the average size of DRXed grain $\left(d_{\mathrm{DRX}}\right)$ decrease with the decrease in extrusion speed, and the corrosion rate of the alloy also shows a downward trend. On the contrary, the values of $V_{\text {pre }}, V_{\mathrm{DRX}}$ and $d_{\mathrm{DRX}}$ increase with the increase in extrusion temperature, and the corrosion resistance of $\mathrm{Mg}-4 \mathrm{Zn}-2 \mathrm{Gd}-$ $0.5 \mathrm{Ca}$ alloy decreases. When the extrusion speed is $0.01 \mathrm{~mm} / \mathrm{s}$ and the extrusion temperature is $280{ }^{\circ} \mathrm{C}$, the alloy has the best corrosion resistance. The corrosion of extruded $\mathrm{Mg}-4 \mathrm{Zn}-2 \mathrm{Gd}-0.5 \mathrm{Ca}$ alloy occurs preferentially on the magnesium matrix around W and I phases in the DRXed zone. With the further corrosion, the corrosion continues to spread along the phase, and the corrosion area gradually increases. Galvanic corrosion plays a leading role in the corrosion process. Moreover, there are a large number of basal plane textures in the unDRXed region, which is conducive to improving the corrosion resistance of magnesium alloys. In addition, the decrease in grain size also makes the corrosion of magnesium alloy more uniform.
\end{abstract}

Keywords Mg-4Zn-2Gd-0.5Ca alloy · Extrusion · EIS (electrochemical impedance spectroscopy) · Weight loss · Corrosion resistance

\section{Introduction}

As structural and functional material, $\mathrm{Mg}$ and its alloy present many properties owing to its high specific strength, rigidity and good electromagnetic shielding properties. These performances make $\mathrm{Mg}$ alloy very attractive for applications in aerospace, automotive and electronic industries [1-4]. Moreover, due to the good biocompatibility and suitable degradation speed, $\mathrm{Mg}$ alloy also has a trend to replace traditional stainless steel as biomaterials [5, 6]. However, its application is limited because of the lower strength as well as the poor corrosion resistance [7-9]. Therefore, obtaining $\mathrm{Mg}$ alloy with high strength and corrosion performance has become a central issue in the current research filed.

Available online at http://link.springer.com/journal/40195

Kun-Kun Deng

jamsdk@163.com; dengkunkun@tyut.edu.cn

1 Shanxi Key Laboratory of Advanced Magnesium-Based Materials, College of Materials Science and Engineering, Taiyuan University of Technology, Taiyuan 030024, China
The poor corrosion resistance of $\mathrm{Mg}$ alloy is mainly attributed to two aspects: (1) the lower electrochemical potential ( $-2.37 \mathrm{~V}$ vs SCE) and magnesium matrix often act as anode dissolved preferentially in the electrolyte; (2) the protective film is not as dense as the protective film of stainless steel and Al alloy [10-12]. Many efforts have been made to modify the anti-corrosion performance of $\mathrm{Mg}$ alloy, such as alloying and coating [13-18], of which the alloying can improve the corrosion resistance essentially [15], and the $\mathrm{Mg}-\mathrm{Zn}-\mathrm{RE}$ alloys have received the most concern [8, 19-21]. Among them, Yuan et al. [8] investigated the microstructure, mechanical properties and corrosion of $\mathrm{Mg}-2.4 \mathrm{Zn}-0.8 \mathrm{Gd}(\mathrm{wt} \%)$ alloy with and without solution treatment before extrusion in vitro. The research results show that the volume of secondary phases decreased after solution treatment, leading to more homogeneous microstructure distribution of as-extruded samples. The corrosion resistance was improved by about $20 \%$ according to hydrogen evolution and weight loss test. Zhang et al. [20] studied the microstructure, biocorrosion behavior and cytotoxicity of an as-extruded $\mathrm{Mg}-11.3 \mathrm{Gd}-2.5 \mathrm{Zn}-0.7 \mathrm{Zr}$ (wt\%) alloy. The results show 
that the microstructure of the as-extruded alloy mainly consists of the refinement grains. The corrosion rate in Hanks' solution is only $0.17 \mathrm{~mm} / \mathrm{year}$, and the corrosion mode of the alloy is uniform corrosion, which is much better than that of as-extruded $\mathrm{Mg}-10.2 \mathrm{Gd}-3.3 \mathrm{Y}-0.6 \mathrm{Zr}$ $(\mathrm{wt} \%)$ alloy. There are long period stacking ordered (LPSO) phase, $\mathrm{W}$ phase $\left(\mathrm{Mg}_{3} \mathrm{Zn}_{3} \mathrm{RE}_{2}\right)$ and I phase $\left(\mathrm{Mg}_{3} \mathrm{Zn}_{6} \mathrm{RE}\right)$ formed when $\mathrm{Zn} / \mathrm{RE}$ atomic ratio is different, which would influence its mechanical properties and corrosion resistance. As reported the corrosion resistance of $\mathrm{Mg}_{95.5} \mathrm{Gd}_{3.5} \mathrm{Zn}_{1}$ with LPSO phase is better than that those without LPSO phase owing to the less accelerating corrosion process of LPSO phase [22], which was in agreement with Zhang's study [23]. Xu et al. [24] pointed out that the quasicrystal I phase has a series of advantages, such as high hardness, low interfacial energy, outstanding corrosion resistance, etc. Although the strength of rare earth $\mathrm{Y}$ containing $\mathrm{Mg}-\mathrm{Zn}-\mathrm{RE}$ alloys was enhanced with the increase in I phase [25], the corrosion mechanism of I phase on $\mathrm{Mg}-\mathrm{Zn}-\mathrm{RE}$ alloy is not clear.

Besides, studies have displayed that the addition of $\mathrm{Ca}$ had an important influence on the microstructure of $\mathrm{Mg}$ alloys by refining grain size and scattering the particles to lead to a more uniformed distribution which can further affect the corrosion behavior and mechanical properties [26-28]. Zeng et al. [26] analyzed the microstructure, composition and the corrosion resistance of $\mathrm{Mg}-\mathrm{Ca}$ alloys. The results revealed that Ca played a dual role, decreasing the corrosion rate due to the refinement of grain size and accelerating corrosion due to the formation of the $\mathrm{Mg}_{2} \mathrm{Ca}$ phase. The $\mathrm{Mg}_{2} \mathrm{Ca}$ particles coexisted with $\mathrm{Fe}$ and $\mathrm{Si}$ leading to pitting corrosion.

Thermodynamic deformation (hot rolling, extrusion, etc.) has been reported to enhance the mechanical properties and corrosion resistance of $\mathrm{Mg}$ alloy [11, 29-31]. Li et al. [31] pointed out that excellent mechanical properties could be achieved with the YS of $324 \mathrm{MPa}$ and UTS of $371 \mathrm{MPa}$ for $\mathrm{Mg}-4 \mathrm{Zn}-0.5 \mathrm{Ca}$ alloy extruded at $0.01 \mathrm{~mm} / \mathrm{s}$. Furthermore, the type, amount and distribution of phase also changed during deformation process which affects the corrosion resistance. Wu et al. [11] reported that the corrosion properties of $\mathrm{Mg}-\mathrm{Al}-\mathrm{Ca}$ alloys was improved after extrusion due to the broken of $(\mathrm{Mg}, \mathrm{Al})_{2} \mathrm{Ca}$ or $\mathrm{Al}_{2} \mathrm{Ca}$ and grain refinement. Cao et al. [30] pointed out that the corrosion resistance of $\mathrm{Mg}-\mathrm{Gd}, \mathrm{Mg}-\mathrm{Ca}$ and $\mathrm{Mg}-\mathrm{Al}$ alloys could be improved after hot rolling due to the more homogeneous microstructure as well as the less, smaller secondary phase. At present, there are few reports about the corrosion performance of $\mathrm{Mg}-\mathrm{Zn}-\mathrm{Ca}$ alloy with rare earth element. Herein, the corrosion behavior of $\mathrm{Mg}-4 \mathrm{Zn}-0.5 \mathrm{Ca}$ alloy containing Gd under different extrusion speeds and temperatures was studied and discussed in this study.

\section{Experimental}

\subsection{Material Preparation}

$\mathrm{Mg}-4 \mathrm{Zn}-2 \mathrm{Gd}-0.5 \mathrm{Ca}(\mathrm{wt} \%)$ alloy was prepared by traditional casting method with an resistance furnace melting of high-purity $\mathrm{Mg}$ (99.95\%), Zn (99.95\%), Ca (99.95\%) and $\mathrm{Mg}-30 \mathrm{Gd}$ master alloy under a shielding gas of $\mathrm{CO}_{2}$ and $\mathrm{SF}_{6}$, of which the volume ration is $40: 1$, and then, they were cast into a mold with a diameter of $41 \mathrm{~mm}$ preheated to $250{ }^{\circ} \mathrm{C}$. After that, two steps of homogenization treatment were applied: firstly, the ingot was homogenized at $430{ }^{\circ} \mathrm{C}$ for $16 \mathrm{~h}$, and then, it was treated at the temperature to $510{ }^{\circ} \mathrm{C}$ for $20 \mathrm{~h}$. The ingot for extrusion was machined with a diameter of $40 \mathrm{~mm}$ and a length of $45 \mathrm{~mm}$. For different extrusion speeds, the ingots were extruded at $280{ }^{\circ} \mathrm{C}$ with speed of $0.01,0.05$ and $0.1 \mathrm{~mm} / \mathrm{s}$, respectively. And the ingots were denoted as $280-0.01,280-0.05$ and 280-0.1, respectively. For different temperatures of extrusion, the ingots were extruded at $0.01 \mathrm{~mm} / \mathrm{s}$ with temperature of 320 and $360{ }^{\circ} \mathrm{C}$, respectively. And the ingots were denoted as 320-0.01 and 360-0.01, respectively. The extrusion ratio of all extruded specimens was 16:1. Finally, the rods of $10 \mathrm{~mm}$ in diameter were obtained. The corresponding experimental device in this study is shown in Fig. 1.

\subsection{Microstructure Observation}

The actual chemical compositions of $\mathrm{Mg}-4 \mathrm{Zn}-2 \mathrm{Gd}-0.5 \mathrm{Ca}$ alloy are listed in Table 1 . The specimens for microstructure observation were machined parallel to the direction of extrusion and then ground, polished and etched. OM (optical microscopy, 4XC) and scanning electron microscopy (SEM) were used to observe the microstructure as well as the corrosion morphology. The average size $\left(d_{\text {DRX }}\right)$ and volume fraction $\left(V_{\mathrm{DRX}}\right)$ of dynamic recrystallization grains and precipitates were measured using Image-Pro Plus 6.0 (Media Cybernetics, Bethesda, Maryland). The chemical composition of the phase was determined by XRD (X-ray diffractometer, DX-2700), SEM with EDS (energy-dispersive spectrometer) and TEM (transmission electron microscopy, JEM-2100) combined with EDS. The scanning range of XRD was $20^{\circ}-80^{\circ}$, and the scan rate was $2 \% \mathrm{~min}$. The obtained results were analyzed using MDI Jade 6.0 software. TEM sample was ground to below $50 \mu \mathrm{m}$ firstly, and then, it underwent ion-thinning with an ion accelerating voltage of $200 \mathrm{kV}$. 


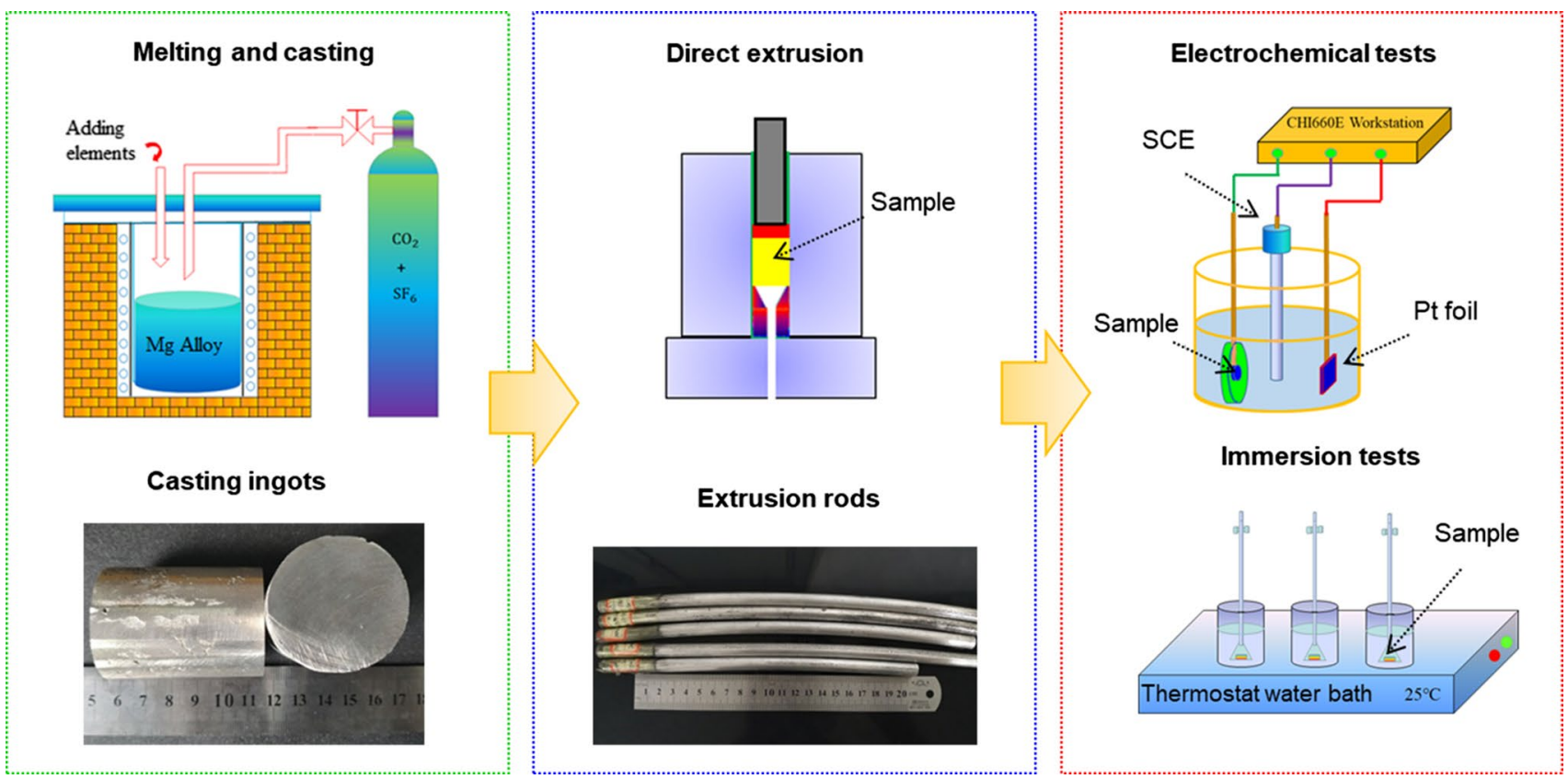

Fig. 1 Schematic for the experimental device in this study

\subsection{Immersion Tests}

Table 1 Actual chemical compositions of $\mathrm{Mg}-4 \mathrm{Zn}-2 \mathrm{Gd}-$ $0.5 \mathrm{Ca}$ alloy (wt $\%)$

\begin{tabular}{llll}
\hline $\mathrm{Zn}$ & $\mathrm{Gd}$ & $\mathrm{Ca}$ & $\mathrm{Mg}$ \\
\hline 4.2 & 2.1 & 0.3 & Balance \\
\hline
\end{tabular}

\subsection{Electrochemical Tests}

Electrochemical tests were carried on at $25 \pm 1{ }^{\circ} \mathrm{C}$ using a three-electrode system with a saturated calomel electrode (SCE) acting as reference electrode, a platinum electrode acting as counter electrode and the specimen acting as working electrode. Before tests, the working electrode was connected to a copper wire and sealed up with epoxy resin leaving an uncovered surface of $10 \mathrm{~mm}$ in diameter, and then it was ground, polished, washed and dried. Prepared specimens were soaked in $3.5 \mathrm{wt} \% \mathrm{NaCl}$ solution for $0.5 \mathrm{~h}$ to get a steady open circuit potential (OCP, V vs $\mathrm{SCE})$. After that, electrochemical impedance spectroscopy (EIS) measurements were accomplished within a frequency range of $100 \mathrm{k} \mathrm{Hz}-0.01 \mathrm{~Hz}$ accompanied by the amplitude of $5 \mathrm{mV}$. The corresponding EIS information and fitted curves were obtained by ZSimpwin. Prior to potentiodynamic polarization test, the samples were immersed in $3.5 \mathrm{wt} \% \mathrm{NaCl}$ solution for $60 \mathrm{~min}$; polarization tests were conducted with a scan rate of $0.5 \mathrm{mV} \mathrm{s}^{-1}$ from -1.9 to $-1.3 \mathrm{~V}$.
The as-extruded $\mathrm{Mg}-4 \mathrm{Zn}-2 \mathrm{Gd}-0.5 \mathrm{Ca}$ alloys were immersed in $3.5 \mathrm{wt} \% \mathrm{NaCl}$ solution and sustained for $148 \mathrm{~h}$ at $25 \pm 1^{\circ} \mathrm{C}$. The specimens for immersion test were machined parallel to the direction of extrusion with a $5 \mathrm{~mm}$ radius and $5 \mathrm{~mm}$ thickness and sealed with epoxy resin and then ground to 4000\#, polished and weighted. Hydrogen evolution and weight loss experiments were performed simultaneously. An inverted funnel and an acid burette were placed above the specimen soaked in the beaker to record the produced hydrogen volume and recorded every $4 \mathrm{~h}$; then, the hydrogen evolution rate [HER, $\left.\mathrm{ml} /\left(\mathrm{cm}^{2} \cdot \mathrm{h}\right)\right]$ was calculated. After immersion, the corrosion products formed on the surface were washed away using $200 \mathrm{~g} / \mathrm{L} \mathrm{CrO}{ }_{3}+10 \mathrm{~g} / \mathrm{L} \mathrm{AgNO}_{3}$, and then, the specimens were dried and weighted again. The weight loss $\Delta m$ can be translated into corrosion rate $C_{\mathrm{w}}$ (mm/year) using the following formula [11]:

$C_{\mathrm{w}}=\frac{2.1 \Delta m}{A t}$,

here $C_{\mathrm{w}}$ was the corrosion rate (mm/year); $\Delta m$ was the weight loss (mg); $A$ was the exposed area of the specimens $\left(\mathrm{cm}^{2}\right) ; t$ was the immersion time (day). 

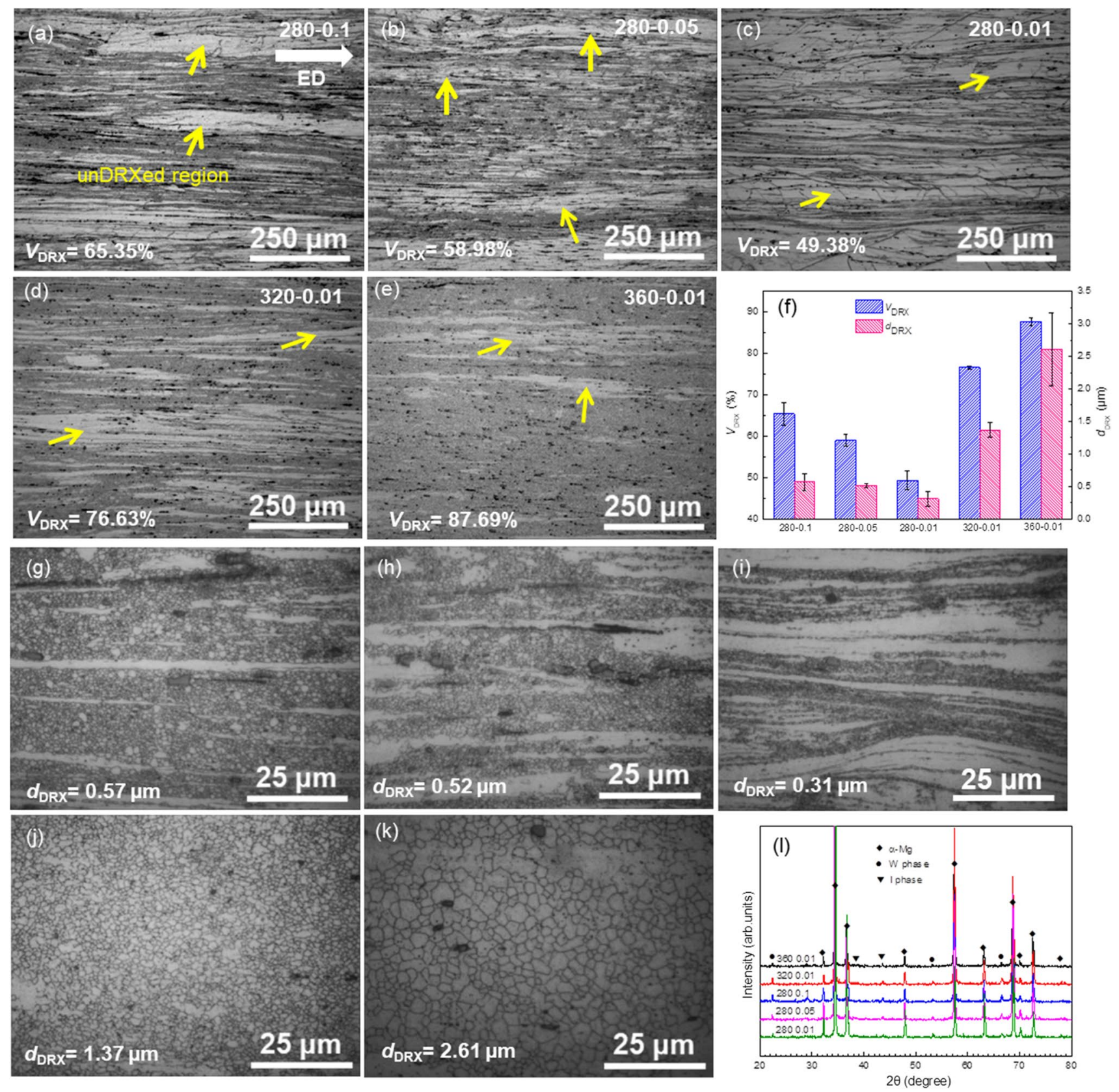

Fig. $2 \mathrm{OM}$ of as-extruded $\mathrm{Mg}-4 \mathrm{Zn}-2 \mathrm{Gd}-0.5 \mathrm{Ca}$ alloy: a, g $280{ }^{\circ} \mathrm{C}, 0.1 \mathrm{~mm} / \mathrm{s}, \mathbf{b}, \mathbf{h} 280{ }^{\circ} \mathrm{C}, 0.05 \mathrm{~mm} / \mathrm{s}, \mathbf{c}, \mathbf{i} 280{ }^{\circ} \mathrm{C}, 0.01 \mathrm{~mm} / \mathrm{s}, \mathbf{d}, \mathbf{j} 320{ }^{\circ} \mathrm{C}$, $0.01 \mathrm{~mm} / \mathrm{s}, \mathbf{e}, \mathbf{k} 360^{\circ} \mathrm{C}, 0.01 \mathrm{~mm} / \mathrm{s}$, f $V_{\mathrm{DRX}}$ and $d_{\mathrm{DRX}}$ of the $\mathrm{Mg}-4 \mathrm{Zn}-2 \mathrm{Gd}-0.5 \mathrm{Ca}$ alloy, $\mathbf{I}$ XRD pattern of as-extruded Mg-4Zn-2Gd-0.5Ca alloy

\section{Results}

\subsection{Microstructures of As-Extruded Mg-4Zn-2Gd- 0.5Ca Alloy}

Figure 2 depicts the OM, the DRXed rate and the DRXed grain size of as-extruded $\mathrm{Mg}-4 \mathrm{Zn}-2 \mathrm{Gd}-0.5 \mathrm{Ca}$ alloy parallel to extrusion direction (ED) at different extrusion speeds and temperatures. It can be obviously seen that the as-extruded alloy consists of unDRXed area with strip distribution along the extrusion direction and DRXed regions with fine grains in the low magnification map of Fig. 2a-e. The $d_{\mathrm{DRX}}$ is only $0.31 \mu \mathrm{m}$ when extruded at $0.01 \mathrm{~mm} / \mathrm{s}, 280{ }^{\circ} \mathrm{C}$; however, $V_{\text {DRX }}$ is only $49.4 \%$. The $V_{\text {DRX }}$ and $d_{\text {DRX }}$ increase gradually and the strip distribution in unDRXed area decreases with increasing the extrusion speed and temperature.

The XRD results (Fig. 21) show that the as-extruded alloy consists of $\alpha-\mathrm{Mg}, \mathrm{W}$ phase $\left(\mathrm{Mg}_{3} \mathrm{Zn}_{3} \mathrm{Gd}_{2}\right)$ and I phase $\left(\mathrm{Mg}_{3} \mathrm{Zn}_{6} \mathrm{Gd}\right)$. The SEM morphology of as-extruded $\mathrm{Mg}-4 \mathrm{Zn}-2 \mathrm{Gd}-0.5 \mathrm{Ca}$ alloy parallel to the extrusion direction 
at different extrusion speeds and temperatures is presented in Fig. 3. Distinctly to observed in Fig. 3a, c, e, g, i, the secondary phase distributed in strips along extrusion direction and the EDS results (Table 2) display the secondary phase containing $\mathrm{Mg}, \mathrm{Zn}$ and $\mathrm{Gd}$; the $\mathrm{Zn} / \mathrm{Gd}$ ratio is about 3:2 which is close to $\mathrm{W}$ phase. Combining with the XRD analysis, it can be determined that the secondary phase is $\mathrm{W}$ phase. Besides that, the spherical precipitate distributed within the grain boundaries and at grain interiors of the DRXed region can be seen at the high magnification in Fig. 3b, d, f, h, j. Figure 4 presents the TEM result of the as-extruded 360-0.01 alloy, and the spherical precipitate can also be seen in Fig. 4a. The EDS analysis for the precipitate marked by arrow in Fig. $4 \mathrm{~b}$ shows that the main elements contain $\mathrm{Mg}, \mathrm{Zn}$ and $\mathrm{Gd}$; the $\mathrm{Zn} / \mathrm{Gd}$ ratio is about 6 which is close to I phase. Combining with the XRD analysis, it can be determined that the spherical precipitate is I phase. It is worth noting that the $V_{\text {pre }}$ of I phase increases with increasing extrusion speed and temperature.

\subsection{Electrochemical Measurements}

Figure 5 shows the OCP curve of as-extruded $\mathrm{Mg}-4 \mathrm{Zn}-2 \mathrm{Gd}-0.5 \mathrm{Ca}$ alloy immersed in $3.5 \mathrm{wt} \% \mathrm{NaCl}$ solution for $0.5 \mathrm{~h}$. The OCP of all the alloys increases drastically in the first $200 \mathrm{~s}$ and then grows a little bit obtaining a relatively stable value after immersion for about $30 \mathrm{~min}$. Generally speaking, the increase in the OCP potential value indicates the formation of the corrosion layer over the time [32]; the more positive value means the higher fraction corrosion layer formed [33]. But only OCP value is not sufficient to explain the corrosion resistance of the alloy.

Figure 6 displays the EIS diagrams of Nyquist and Bode plots. The Nyquist plot (Fig. 6a) consisted of three welldefined flat semicircle loops, and the diameters are different indicating the same corrosion mechanism, but different corrosion rates. The three loops correspond to the high-frequency capacitive loop, middle-frequency capacitive loop and low-frequency inductive loop, respectively, which is relative to the wave crest and wave trough (Fig. 6c). Ordinarily speaking, the high-frequency capacitive loop represents the charge transfer process and the specimens begin to deteriorate; the middle-frequency capacitive loop attributed to the generation and diffusion of porous film of the alloy, and the porous film is probably $\mathrm{Mg}(\mathrm{OH})_{2}[34,35]$; the inductive loop indicates the $\mathrm{Cl}^{-}$penetrates the porous film and infiltrate the substrate.

As for the $\mathrm{Mg}-4 \mathrm{Zn}-2 \mathrm{Gd}-0.5 \mathrm{Ca}$ alloy extruded at $280^{\circ} \mathrm{C}$ with different speeds, the diameter of the semicircle loops decreases with increasing the extrusion rate, which is related to the worse corrosion performance of the alloy. The Bode plots (Fig. 6b) of extrusion alloy at $0.01 \mathrm{~mm} / \mathrm{s}$ are higher than others, which are corresponding well with the Nyquist plots. As for the specimen extruded at different temperatures, the corrosion resistance is the best when the extrusion temperature is $280{ }^{\circ} \mathrm{C}$. And the corrosion resistance of the alloy decreases with the increase in the extrusion temperature, and the difference of corrosion resistance for the alloy extruded at $320{ }^{\circ} \mathrm{C}$ and $360{ }^{\circ} \mathrm{C}$ is negligible.

To better elucidate the corrosion feature of as-extruded $\mathrm{Mg}-4 \mathrm{Zn}-2 \mathrm{Gd}-0.5 \mathrm{Ca}$ alloy, the fitted circuit model is shown in Fig. 6d. Where $R_{\mathrm{s}}, R_{\mathrm{ct}}, R_{\mathrm{f}}$ and $R_{\mathrm{L}}$ stand for the solution resistance, charge transfer resistance, film resistance and induction resistance, respectively. CPE represents the constant phase element that replaces the electric double-layer capacitor, and $L$ represents the inductance. The relevant electrochemical data are listed in Table 3 . Where $R_{\mathrm{ct}}$ is a measure of the corrosion rate, and its value is inversely proportional to corrosion rate [34]; it is noted that the value of $R_{\mathrm{ct}}$ for the specimen extruded with $0.01 \mathrm{~mm} / \mathrm{s}$ at $280{ }^{\circ} \mathrm{C}$ reached up $1278 \Omega \mathrm{cm}^{2}$ which is the largest of the alloy; that is to say, the specimen for 280-0.01 has the optimal corrosion resistance, which becomes worse with increasing extrusion rate and temperature.

The potentiodynamic polarization curves of as-extruded $\mathrm{Mg}-4 \mathrm{Zn}-2 \mathrm{Gd}-0.5 \mathrm{Ca}$ alloy immersed in $3.5 \mathrm{wt} \% \mathrm{NaCl}$ for $1 \mathrm{~h}$ are depicted in Fig. 7a. Due to negative difference effect (NDE), values of corrosion current density $\left(i_{\text {corr }}\right)$ are obtained by cathode extrapolation. The corrosion potential $\left(E_{\text {corr }}\right)$ and corrosion current density $\left(i_{\text {corr }}\right)$ are presented in Table 4. Generally, the anodic part mainly produces the following reaction:

$\mathrm{Mg}-2 \mathrm{e}^{-} \rightarrow \mathrm{Mg}^{2+}$

The cathode region of the polarization curve mainly produces the following reaction:

$2 \mathrm{H}_{2} \mathrm{O}+2 \mathrm{e}^{-} \rightarrow \mathrm{H}_{2}+2 \mathrm{OH}^{-}$.

In case of the alloy at different extrusion speeds, the difference of the $E_{\text {corr }}$ is very small indicating that the alloys extruded at different conditions have similar thermodynamic characteristic. However, obvious shift to right of cathode branch is observed indicating the value of $i_{\text {corr }}$ increases with increasing extrusion rate; the alloy with the rate of $0.1 \mathrm{~mm} / \mathrm{s}$ at $280{ }^{\circ} \mathrm{C}$ exhibits the highest $i_{\text {corr }}$ of $20.90 \mu \mathrm{A} / \mathrm{cm}^{2}$, which is about three times higher than that in $0.01 \mathrm{~mm} / \mathrm{s}$ at $280{ }^{\circ} \mathrm{C}$, suggesting that the 280-0.1 alloy has a poor corrosion resistance. Song et al. [33] revealed that $i_{\text {corr }}$ is more precise in explaining the corrosion resistance than the $E_{\text {corr }}$. The $E_{\text {corr }}$ merely represent the thermodynamic characteristic rather than the corrosion kinetics. Similarly, in case of the alloy at different extrusion temperatures, the thermodynamic characteristic is similar and the $i_{\text {corr }}$ increases slightly with increasing extrusion temperature. It is worth noting that all the 


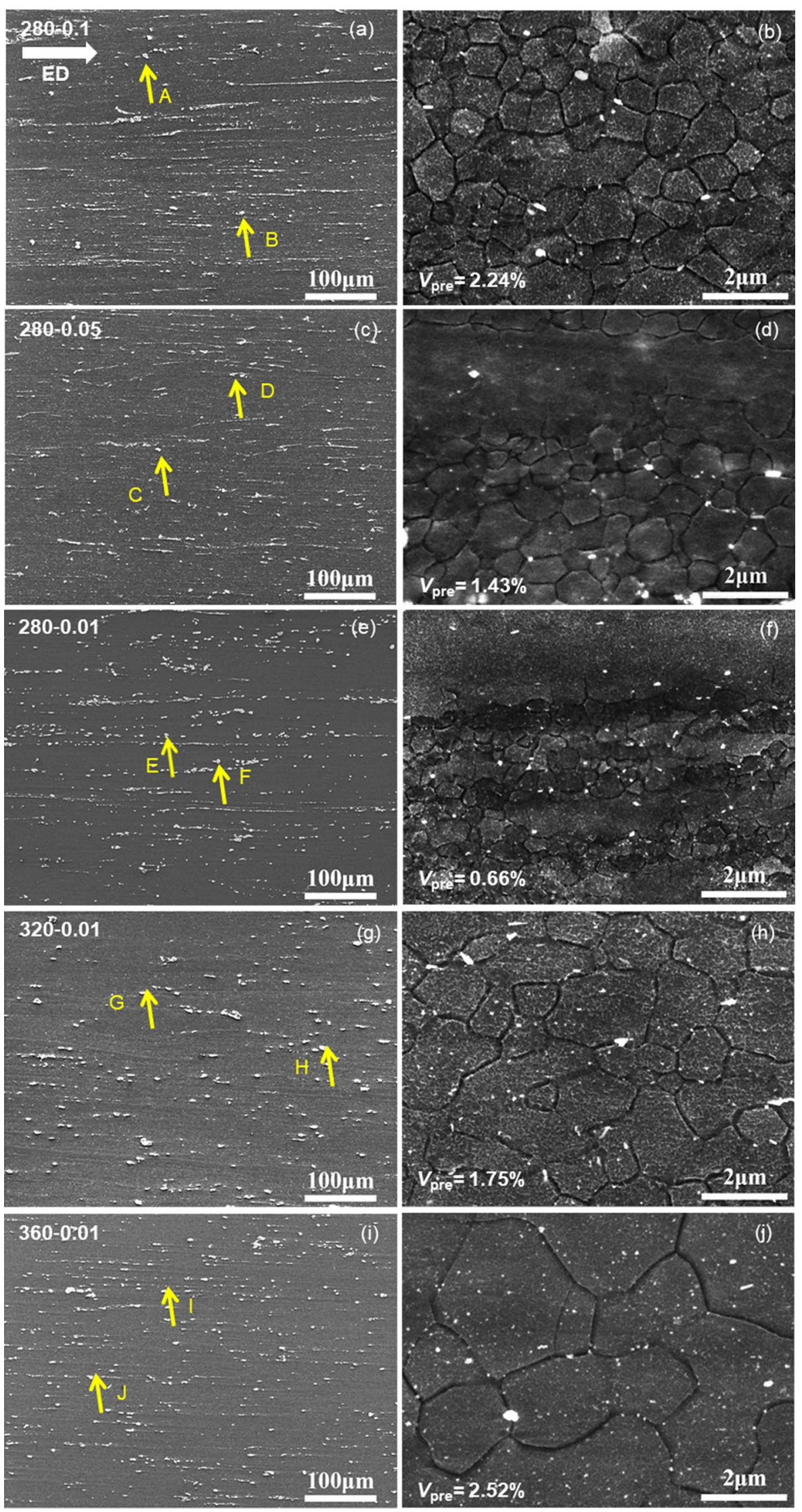


4Fig. 3 SEM microstructures of as-extruded $\mathrm{Mg}-4 \mathrm{Zn}-2 \mathrm{Gd}-0.5 \mathrm{Ca}$ alloy: a, b $280{ }^{\circ} \mathrm{C}, 0.1 \mathrm{~mm} / \mathrm{s}, \mathbf{c}, \mathbf{d} 280{ }^{\circ} \mathrm{C}, 0.05 \mathrm{~mm} / \mathrm{s}$, e, f $280{ }^{\circ} \mathrm{C}$, $0.01 \mathrm{~mm} / \mathrm{s}, \mathbf{g}, \mathbf{h} 320^{\circ} \mathrm{C}, 0.01 \mathrm{~mm} / \mathrm{s}, \mathbf{i}, \mathbf{j} 360^{\circ} \mathrm{C}, 0.01 \mathrm{~mm} / \mathrm{s}$

alloys show an inflection point at the anode branch, which indicates that the surface film is generated on the alloy. When the potential reaches the film breakdown potential, the protective film starts to break up and pitting corrosion occurs [36]. Overall, the alloy with extrusion temperature of $280{ }^{\circ} \mathrm{C}$ at $0.01 \mathrm{~mm} / \mathrm{s}$ has the best corrosion resistance, and the corrosion resistance of specimen extruded at $320{ }^{\circ} \mathrm{C}$ is not far different from that of the specimen extruded at $360{ }^{\circ} \mathrm{C}$.

Table 2 EDS analysis results of as-extruded $\mathrm{Mg}-4 \mathrm{Zn}-2 \mathrm{Gd}-0.5 \mathrm{Ca}$ alloy (at.\%)

\begin{tabular}{llllll}
\hline Positions & \multicolumn{2}{l}{ Elements } & \multicolumn{2}{l}{ Possible compounds } \\
\cline { 2 - 4 } & $\mathrm{Mg}$ & $\mathrm{Zn}$ & $\mathrm{Gd}$ & $\mathrm{Ca}$ & \\
\hline A & 42.7 & 35.0 & 22.2 & 0.0 & W phase $\left(\mathrm{Mg}_{3} \mathrm{Zn}_{3} \mathrm{Gd}_{2}\right)$ \\
B & 27.0 & 54.8 & 18.2 & 0.0 & W phase $\left(\mathrm{Mg}_{3} \mathrm{Zn}_{3} \mathrm{Gd}_{2}\right)$ \\
C & 52.6 & 27.0 & 20.2 & 0.1 & W phase $\left(\mathrm{Mg}_{3} \mathrm{Zn}_{3} \mathrm{Gd}_{2}\right)$ \\
D & 24.8 & 55.7 & 19.5 & 0.0 & W phase $\left(\mathrm{Mg}_{3} \mathrm{Zn}_{3} \mathrm{Gd}_{2}\right)$ \\
E & 25.3 & 54.0 & 20.2 & 0.0 & W phase $\left(\mathrm{Mg}_{3} \mathrm{Zn}_{3} \mathrm{Gd}_{2}\right)$ \\
F & 25.5 & 52.2 & 22.3 & 0.0 & W phase $\left(\mathrm{Mg}_{3} \mathrm{Zn}_{3} \mathrm{Gd}_{2}\right)$ \\
G & 27.6 & 53.9 & 18.4 & 0.0 & W phase $\left(\mathrm{Mg}_{3} \mathrm{Zn}_{3} \mathrm{Gd}_{2}\right)$ \\
H & 27.9 & 53.1 & 19.0 & 0.0 & W phase $\left(\mathrm{Mg}_{3} \mathrm{Zn}_{3} \mathrm{Gd}_{2}\right)$ \\
I & 29.5 & 51.5 & 18.2 & 0.8 & W phase $\left(\mathrm{Mg}_{3} \mathrm{Zn}_{3} \mathrm{Gd}_{2}\right)$ \\
J & 29.6 & 50.5 & 19.9 & 0.0 & W phase $\left(\mathrm{Mg}_{3} \mathrm{Zn}_{3} \mathrm{Gd}_{2}\right)$ \\
\hline
\end{tabular}

The polarization resistance, $R_{\mathrm{p}}$, is a parameter that characterizes corrosion and its reciprocal varies directly as the corrosion rate. $R_{\mathrm{p}}$ was calculated by the equivalent circuit from the following formula:

$R_{\mathrm{p}}=R_{\mathrm{s}}+\frac{R_{\mathrm{ct}}\left(R_{\mathrm{f}}+R_{\mathrm{L}}\right)}{R_{\mathrm{ct}}+R_{\mathrm{f}}+R_{\mathrm{L}}}$.

And the $1 / R_{\mathrm{p}}$ of the $\mathrm{Mg}-4 \mathrm{Zn}-2 \mathrm{Gd}-0.5 \mathrm{Ca}$ alloy immersed in $3.5 \mathrm{wt} \% \mathrm{NaCl}$ for $40 \mathrm{~min}$ is depicted in Fig. 7b. The $280-0.01$ alloy presents the lowest value level of $1 / R_{\mathrm{p}}$ than others. To put it differently, the corrosion rate decreased with decreasing extrusion speed and extrusion temperature.

\subsection{Immersion Measurements}

In order to determine the results obtained by electrochemical measurements, the weight loss and hydrogen evolution tests were conducted, respectively. Figure $8 \mathrm{a}$, b presents the HER and $C_{\mathrm{w}}$ calculated by immersion measurements by immersing in $3.5 \mathrm{wt} \% \mathrm{NaCl}$ solution for $148 \mathrm{~h}$, respectively. The general trend is coinciding with those obtained by potentiodynamic polarization and electrochemical impedance tests. The corrosion rate of the 280-0.01 alloy is the lowest with $7.4 \mathrm{~mm} /$ year, showing up the best corrosion resistance. It has been shown that the HER is relatively stable at the first $60 \mathrm{~h}$ and then improves greatly, which indicates that porous film generated on the surface is destroyed and chloride ion penetrates the porous film into the substrate and induces the corrosion degree to be aggravated.
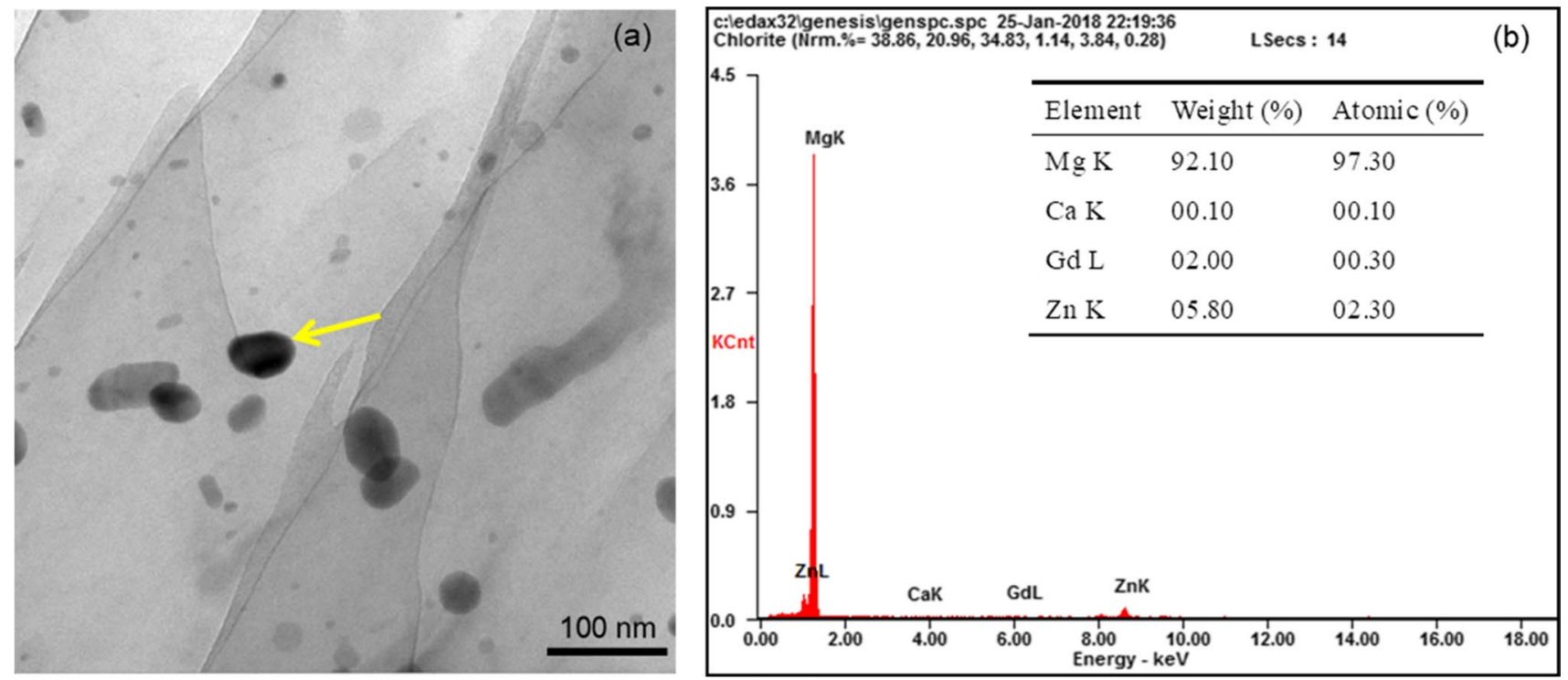

Fig. 4 TEM image of as-extruded $360{ }^{\circ} \mathrm{C} 0.01 \mathrm{~mm} / \mathrm{s} \mathrm{Mg}-4 \mathrm{Zn}-2 \mathrm{Gd}-0.5 \mathrm{Ca}$ alloy, and $\mathbf{b}$ the corresponding EDS of the precipitate pointed by the yellow arrow in $\mathbf{a}$ 


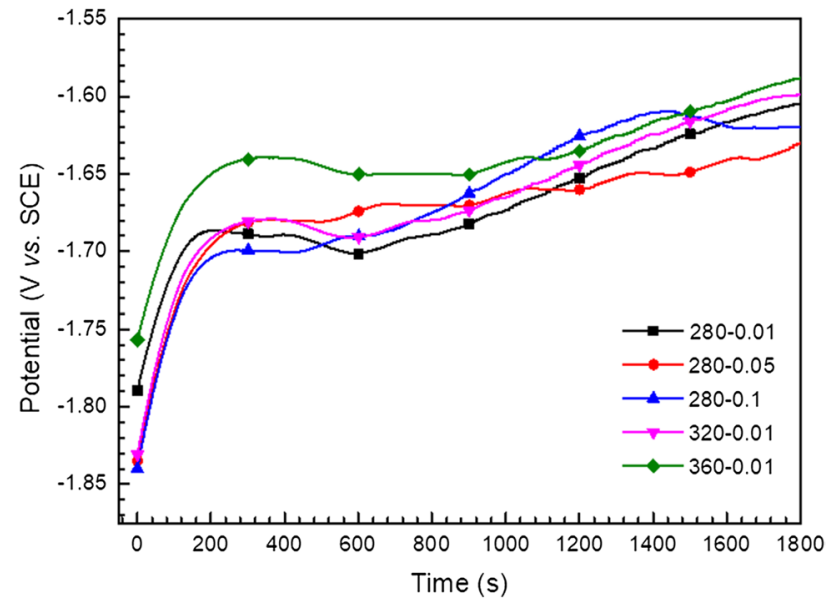

Fig. 5 OCP curves of as-extruded $\mathrm{Mg}-4 \mathrm{Zn}-2 \mathrm{Gd}-0.5 \mathrm{Ca}$ alloy immersed in $3.5 \mathrm{wt} \% \mathrm{NaCl}$ solution for $30 \mathrm{~min}$
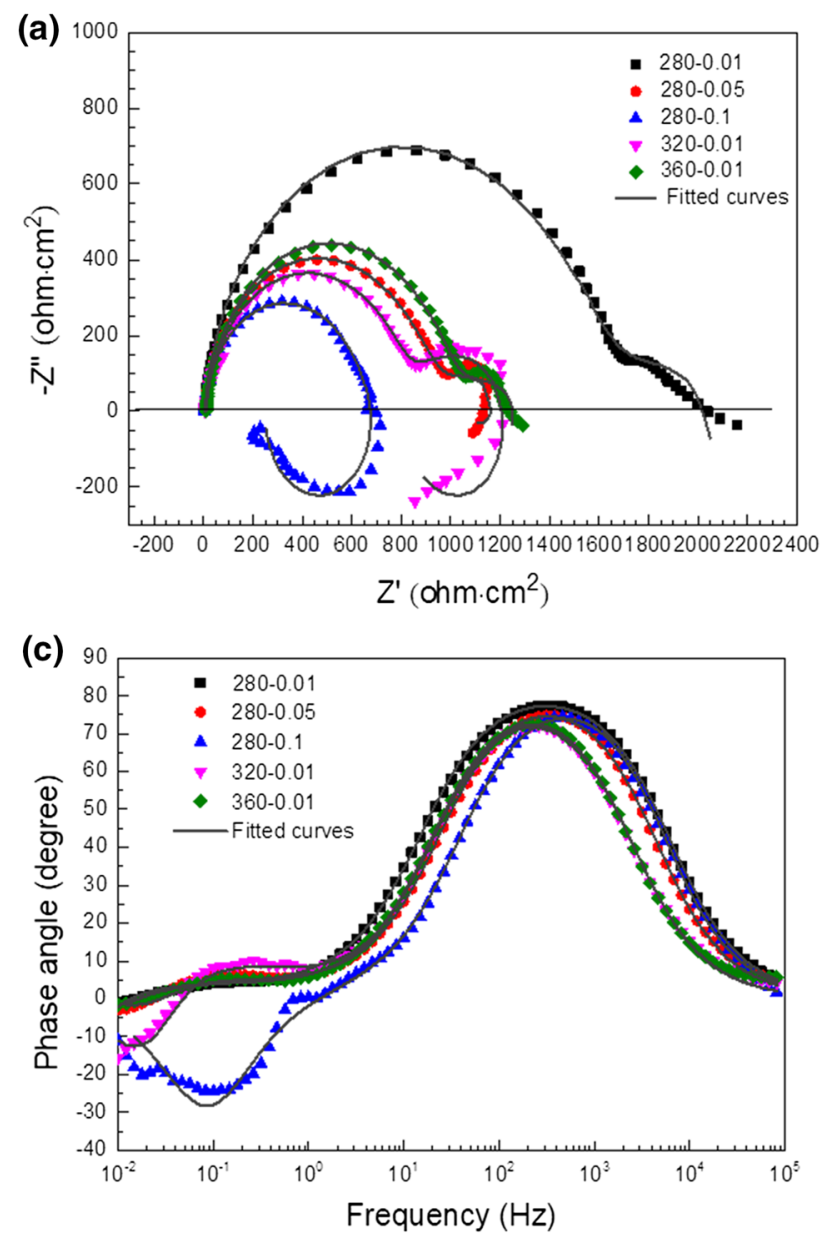

\subsection{Cross-Sectional Corrosion Morphology}

The cross-sectional images of extruded $\mathrm{Mg}-4 \mathrm{Zn}-2 \mathrm{Gd}-0.5 \mathrm{Ca}$ alloys immersed in $3.5 \mathrm{wt} \% \mathrm{NaCl}$ for $148 \mathrm{~h}$ removing the corrosion product are given in Fig. 9. Through long-term immersion, the result shows that the overall corrosion of the 280-0.01 alloy is the shallowest. The corrosion is more serious with increasing extrusion speed and temperature, and the corrosion surface of the 280-0.1 alloy is the most uneven, which is consistent with the results obtained from the EIS, polarization and immersion tests.

\section{Discussion}

According to above electrochemical measurements and immersion tests, the as-extruded 280-0.01 alloy demonstrates the best corrosion resistance, and the corrosion resistance deteriorates with increasing extrusion speed

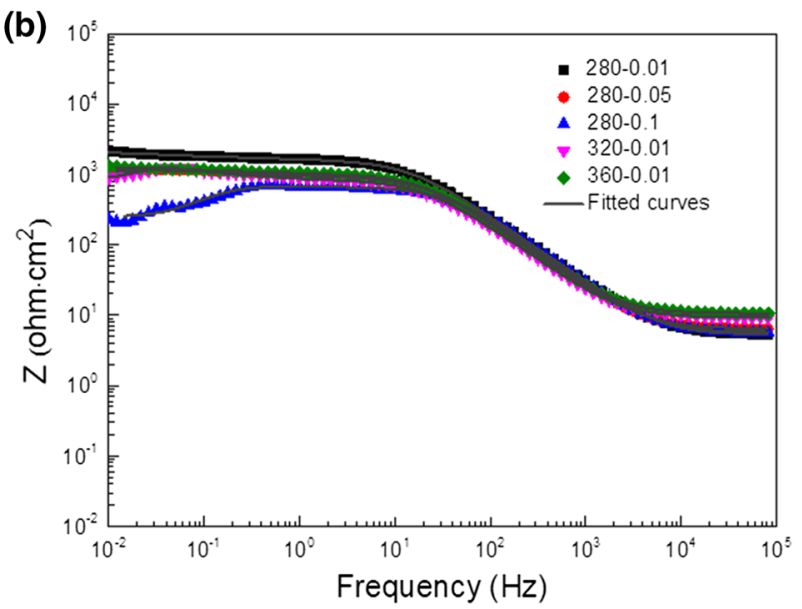

(d)

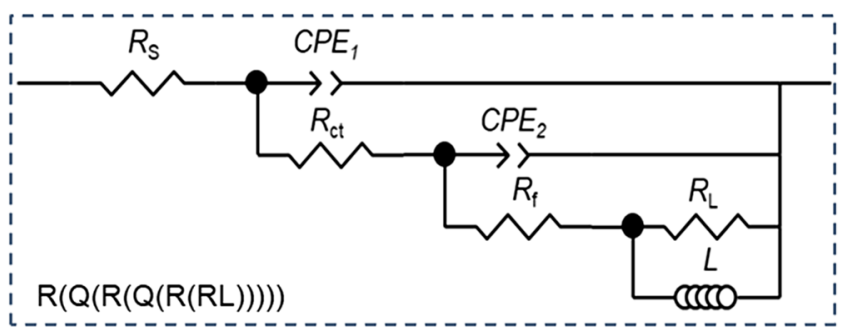

Fig. 6 EIS of as-extruded $\mathrm{Mg}-4 \mathrm{Zn}-2 \mathrm{Gd}-0.5 \mathrm{Ca}$ alloy immersed in $3.5 \mathrm{wt} \% \mathrm{NaCl}$ solution for $40 \mathrm{~min}$. a Nyquist diagrams, b Bode plots of frequency versus $Z$ and $\mathbf{c}$ Bode plots of frequency versus phase angle, $\mathbf{d}$ equivalent circuit of as-extruded $\mathrm{Mg}-4 \mathrm{Zn}-2 \mathrm{Gd}-0.5 \mathrm{Ca}$ alloy. Where the $R_{\mathrm{s}}$ represents the solution resistance; CPE represents the constant phase element; $R_{\mathrm{ct}}$ represents the charge transfer resistance; $R_{\mathrm{f}}$ represents the film resistance; $L$ represents the inductance; and $R_{\mathrm{L}}$ represents the induction resistance 
Table 3 EIS data parameters obtained from EIS analysis of as-extruded $\mathrm{Mg}-4 \mathrm{Zn}-2 \mathrm{Gd}-0.5 \mathrm{Ca}$ alloy immersed in $3.5 \mathrm{wt} \% \mathrm{NaCl}$ solution for $40 \min$

\begin{tabular}{lccccccccc}
\hline Materials & $R_{\mathrm{s}}(\Omega)$ & $\begin{array}{l}\mathrm{CPE}_{1} \\
\left(10^{-6} \mathrm{~s}^{\mathrm{n}} \Omega^{-1} \mathrm{~cm}^{-2}\right)\end{array}$ & $n_{1}$ & $R_{\mathrm{ct}}\left(\Omega \mathrm{cm}^{2}\right)$ & $\begin{array}{l}\mathrm{CPE}_{2}\left(10^{-5}\right. \\
\left.\mathrm{s}^{\mathrm{n}} \Omega^{-1} \mathrm{~cm}^{-2}\right)\end{array}$ & $n_{2}$ & $R_{\mathrm{f}}\left(\Omega \mathrm{cm}^{2}\right)$ & $R_{\mathrm{L}}\left(\Omega \mathrm{cm}^{2}\right)$ & $L(\mathrm{H})$ \\
\hline $280-0.1$ & 5.745 & 8.49 & 0.948 & 33.9 & 7.9 & 0.22 & 225.2 & 490.6 \\
$280-0.05$ & 6.476 & 10.63 & 0.937 & 823.7 & 411.9 & 0.24 & 382.4 & $6.87 \times 10^{10}$ & $4.63 \times 10^{3}$ \\
$280-0.01$ & 5.346 & 9.47 & 0.935 & 1278 & 197.1 & 0.14 & 292 & $4.41 \times 10^{9}$ & $3.78 \times 10^{4}$ \\
$320-0.01$ & 9.316 & 13.77 & 0.929 & 803.9 & 261.3 & 0.63 & 1464 & 538.6 & 3086 \\
$360-0.01$ & 10.54 & 11.61 & 0.935 & 954.1 & 361.7 & 0.43 & 0.01 & 413.8 & $1.26 \times 10^{4}$ \\
\hline
\end{tabular}

(a)

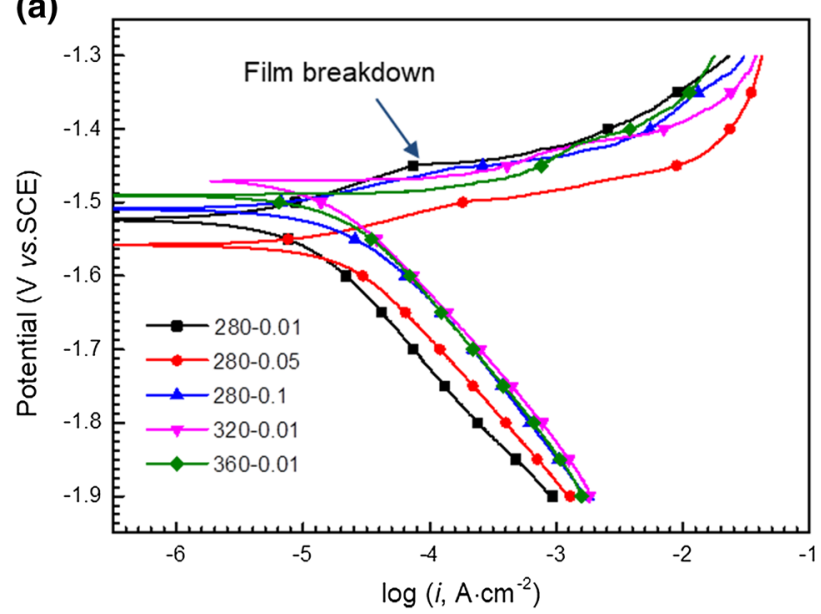

(b)

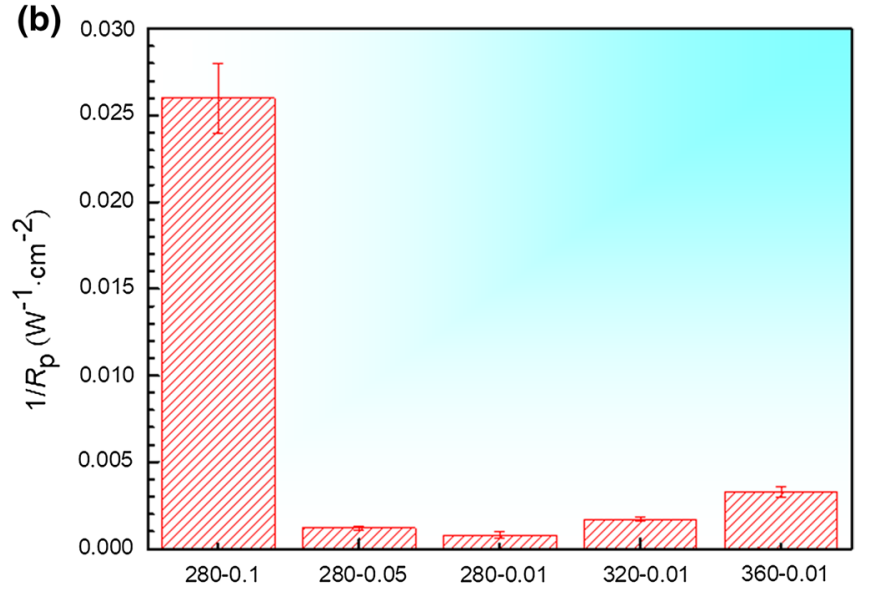

Fig. 7 a Potentiodynamic polarization curves and b $1 / R_{\mathrm{p}}$ of as-extruded $\mathrm{Mg}-4 \mathrm{Zn}-2 \mathrm{Gd}-0.5 \mathrm{Ca}$ alloy immersed in $3.5 \mathrm{wt} \% \mathrm{NaCl}$ solution for $1 \mathrm{~h}$

Table 4 Corrosion potential $\left(E_{\text {corr }}\right)$, cathodic slope $\left(\beta_{\mathrm{c}}\right)$ and corrosion current density $\left(i_{\text {corr }}\right)$ obtained from polarization curves of asextruded $\mathrm{Mg}-4 \mathrm{Zn}-2 \mathrm{Gd}-0.5 \mathrm{Ca}$ alloy immersed in $3.5 \mathrm{wt} \% \mathrm{NaCl}$ solution for $1 \mathrm{~h}$

\begin{tabular}{lllr}
\hline Materials & $E_{\text {corr }}(\mathrm{V}$ vsSCE $)$ & $\beta_{\mathrm{C}}(\mathrm{mv} / \mathrm{dec})$ & $i_{\text {corr }}\left(\mu \mathrm{A} / \mathrm{cm}^{2}\right)$ \\
\hline $280-0.1$ & -1.546 & $-151.31 \pm 38.47$ & $20.90 \pm 9.51$ \\
$280-0.05$ & -1.557 & $-129.12 \pm 1.24$ & $11.40 \pm 2.83$ \\
$280-0.01$ & -1.522 & $-121.34 \pm 3.77$ & $6.35 \pm 2.14$ \\
$320-0.01$ & -1.469 & $-118.99 \pm 1.27$ & $8.42 \pm 0.28$ \\
$360-0.01$ & -1.489 & $-112.02 \pm 11.33$ & $7.55 \pm 4.04$ \\
\hline
\end{tabular}

and extrusion temperature. Generally speaking, corrosion behavior of magnesium alloy strongly depends on its microstructure, such as grain size, the type and quantity of secondary phase, texture, etc. Consequently, Fig. 10 describes the curves of corrosion rate of $\mathrm{Mg}-4 \mathrm{Zn}-2 \mathrm{Gd}-0.5 \mathrm{Ca}$ alloy under different extrusion conditions with $V_{\mathrm{pre}}, V_{\mathrm{DRX}}$ and $d_{\mathrm{DRX}}$. It can be seen that the corrosion resistance of the alloy increases with the decrease in extrusion rate at $280{ }^{\circ} \mathrm{C}$. However, the $V_{\mathrm{pre}}, V_{\mathrm{DRX}}$ and $d_{\mathrm{DRX}}$ show a downward trend. This is mainly attributed to the reduction of precipitates, which reduces the chance of galvanic corrosion between the matrix and the precipitates. Besides, the decrease in $V_{\mathrm{DRX}}$ and $d_{\mathrm{DRX}}$ can help to reduce the corrosion rate of the $\mathrm{Mg}-4 \mathrm{Zn}-2 \mathrm{Gd}-0.5 \mathrm{Ca}$ alloy. Furthermore, when the extrusion rate is $0.01 \mathrm{~mm} / \mathrm{s}$, with increase in extrusion temperature, the $V_{\mathrm{pre}}, V_{\mathrm{DRX}}$ and $d_{\mathrm{DRX}}$ in the matrix increase, and the corrosion resistance of the alloy decreases. In other words, the alloy has the optimum corrosion resistance when the values of the $V_{\mathrm{pre}}, V_{\mathrm{DRX}}$ and $d_{\mathrm{DRX}}$ in the matrix are all low. In addition, compared with the results of Cao et al. [37], the corrosion resistance of $\mathrm{Mg}-4 \mathrm{Zn}-2 \mathrm{Gd}-0.5 \mathrm{Ca}$ alloy $(7.4 \mathrm{~mm} /$ year) extruded at $280{ }^{\circ} \mathrm{C}-0.01 \mathrm{~mm} / \mathrm{s}$ is obviously improved than that of $\mathrm{Mg}-4 \mathrm{Zn}-2 \mathrm{Gd}-0.5 \mathrm{Ca}$ alloy treated by 6 passes of MDF (10.6 mm/year). At the same time, the corrosion resistance of $\mathrm{Mg}-4 \mathrm{Zn}-2 \mathrm{Gd}-0.5 \mathrm{Ca}$ alloy $(7.4 \mathrm{~mm} /$ year) extruded at $280{ }^{\circ} \mathrm{C}-0.01 \mathrm{~mm} / \mathrm{s}$ increased by $57.23 \%$, compared with that of $\mathrm{Mg}-15.24 \mathrm{Gd}-4.75 \mathrm{Zn}$ alloy $(17.3 \mathrm{~mm} /$ year $)$ treated with T4 [38].

To announce the corrosion feature of $\mathrm{Mg}-4 \mathrm{Zn}-2 \mathrm{Gd}-0.5 \mathrm{Ca}$ alloy, its surface morphology is immersed in $3.5 \mathrm{wt} \% \mathrm{NaCl}$ for $40 \mathrm{~min}$ removing the corrosion product as given in Fig. 11. After short time immersion, the mechanism of corrosion under different extrusion 

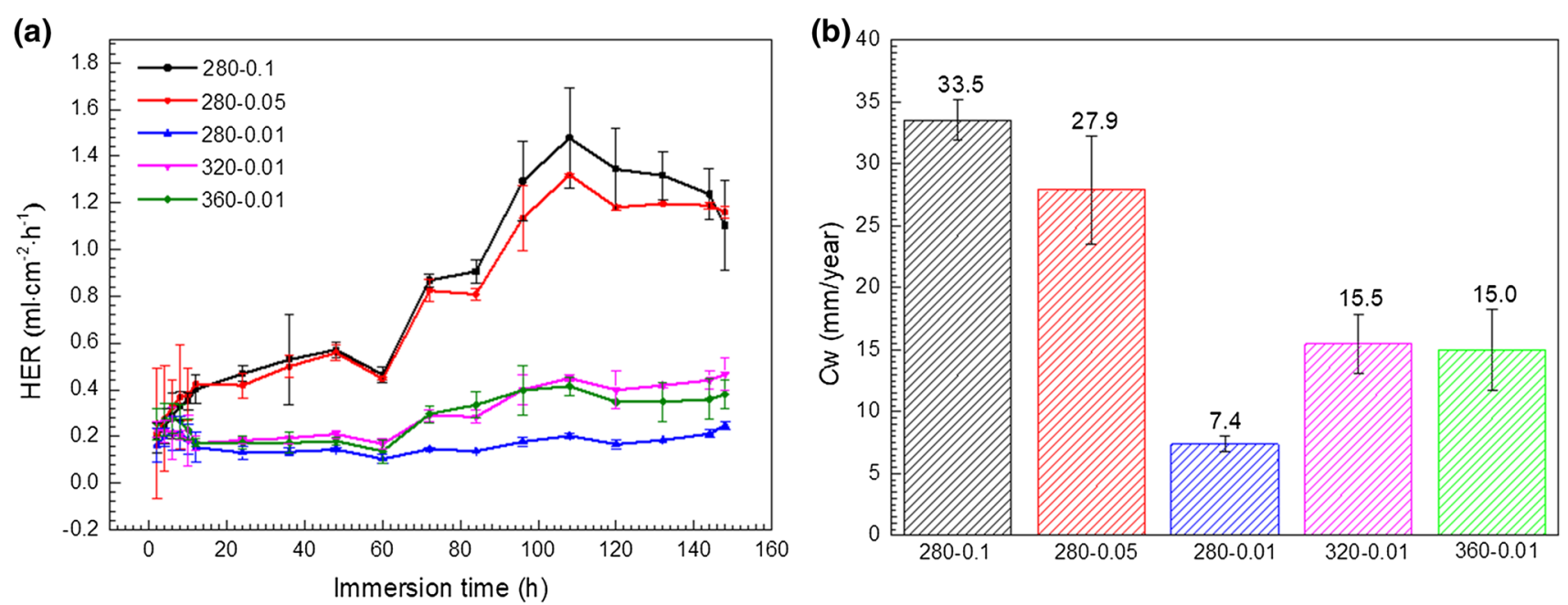

Fig. 8 Immersion test result a hydrogen evolution rate plot and $\mathbf{b}$ weight loss of as-extruded $\mathrm{Mg}-4 \mathrm{Zn}-2 \mathrm{Gd}-0.5 \mathrm{Ca}$ alloy immersed in $3.5 \mathrm{wt} \%$ $\mathrm{NaCl}$ solution for $148 \mathrm{~h}$

(a)

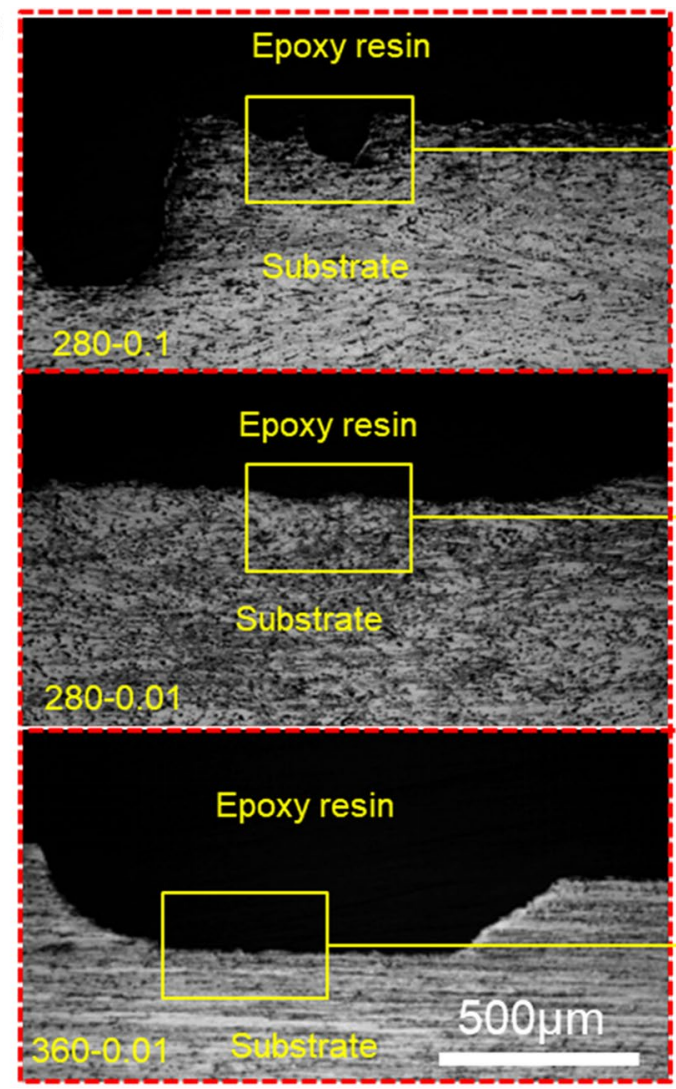

(b)

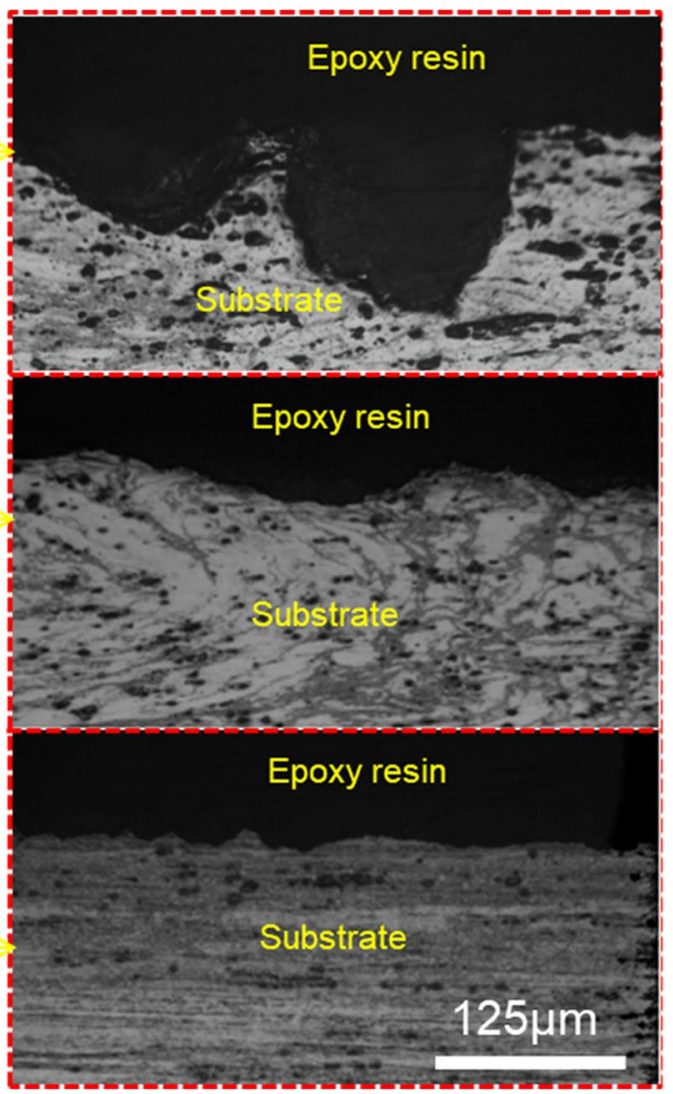

Fig. 9 Section corrosion morphology of as-extruded $\mathrm{Mg}-4 \mathrm{Zn}-2 \mathrm{Gd}-0.5 \mathrm{Ca}$ alloy immersed in $3.5 \mathrm{wt} \% \mathrm{NaCl}$ solution for $148 \mathrm{~h}$ : a low magnification; $\mathbf{b}$ high magnification

parameters is the same, all of which showing two kinds of corrosion morphology. Some show the uniform corrosion morphology, as shown by the yellow arrows in Fig. 11a, d, g. The other corrosion morphology is galvanic corrosion, as depicted in Fig. 11b, e, h. Abundant shallow corrosion pits on the surface and on corroded $\alpha-\mathrm{Mg}$ substrate around the 


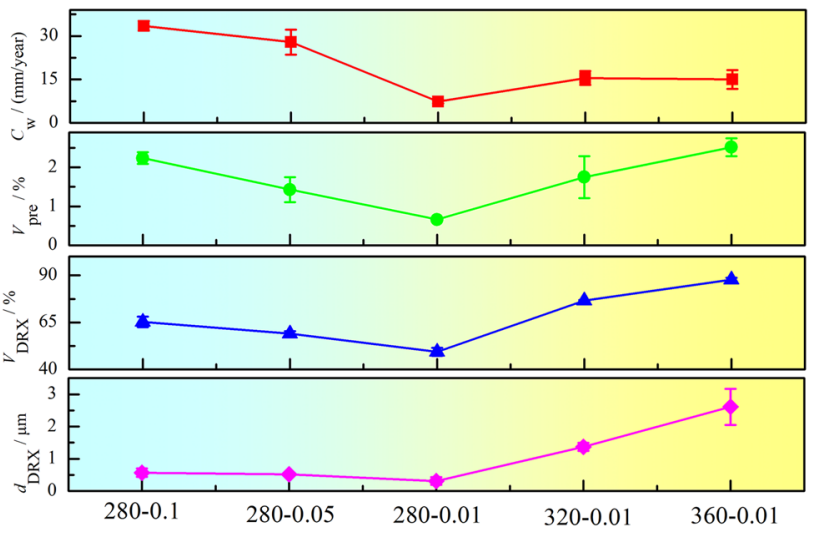

Fig. 10 Curves of corrosion rate of $\mathrm{Mg}-4 \mathrm{Zn}-2 \mathrm{Gd}-0.5 \mathrm{Ca}$ alloy under different extrusion conditions with $V_{\mathrm{pre}}, V_{\mathrm{DRX}}$ and $d_{\mathrm{DRX}}$

phase in high magnification map of Fig. 11c, f, i are shown by yellow arrows and white arrows, respectively. This may be caused by the stringer-shape dispersed $\mathrm{W}$ phase and precipitated I phase.

During the period of corrosion, the standard electrode potential of $\mathrm{W}$ phase and I phase is higher than $\alpha-\mathrm{Mg}$ substrate [21] and the site where the potential is lower acts as anode with respect to the higher potential; galvanic couple generates between the phase and $\alpha-\mathrm{Mg}$ substrate, and substrate is preferentially corroded as the anode. Corrosion continually propagates along the horizontal direction, and the phase will fall off when the surrounding $\alpha-\mathrm{Mg}$ substrate is sufficiently dissolved, leading to the formation of circular corrosion pits.

Nevertheless, it should be note that the degree of DRX strongly depends on extrusion conditions. The DRX is incompletely in present extrusion conditions, the microstructure of which contains both the unDRXed regions and DRXed regions, as described in Fig. 2. As compared with the DRXed regions, the basal plane texture is much stronger in the unDRXed regions [39]. It has been verified that the $\mathrm{Mg}$ alloys with strong basal plane texture usually possess the lower corrosion rate for the reason that the basal plane owns stronger atomic bonding and higher atomic coordination [40]. On the contrary, the W phase and I phase are mainly distributed in the DRXed region and the corrosion occurred preferentially at this place. Besides, the precipitated I phase in unDRXed regions is far less than that in the DRXed regions. That means the

280-0.1
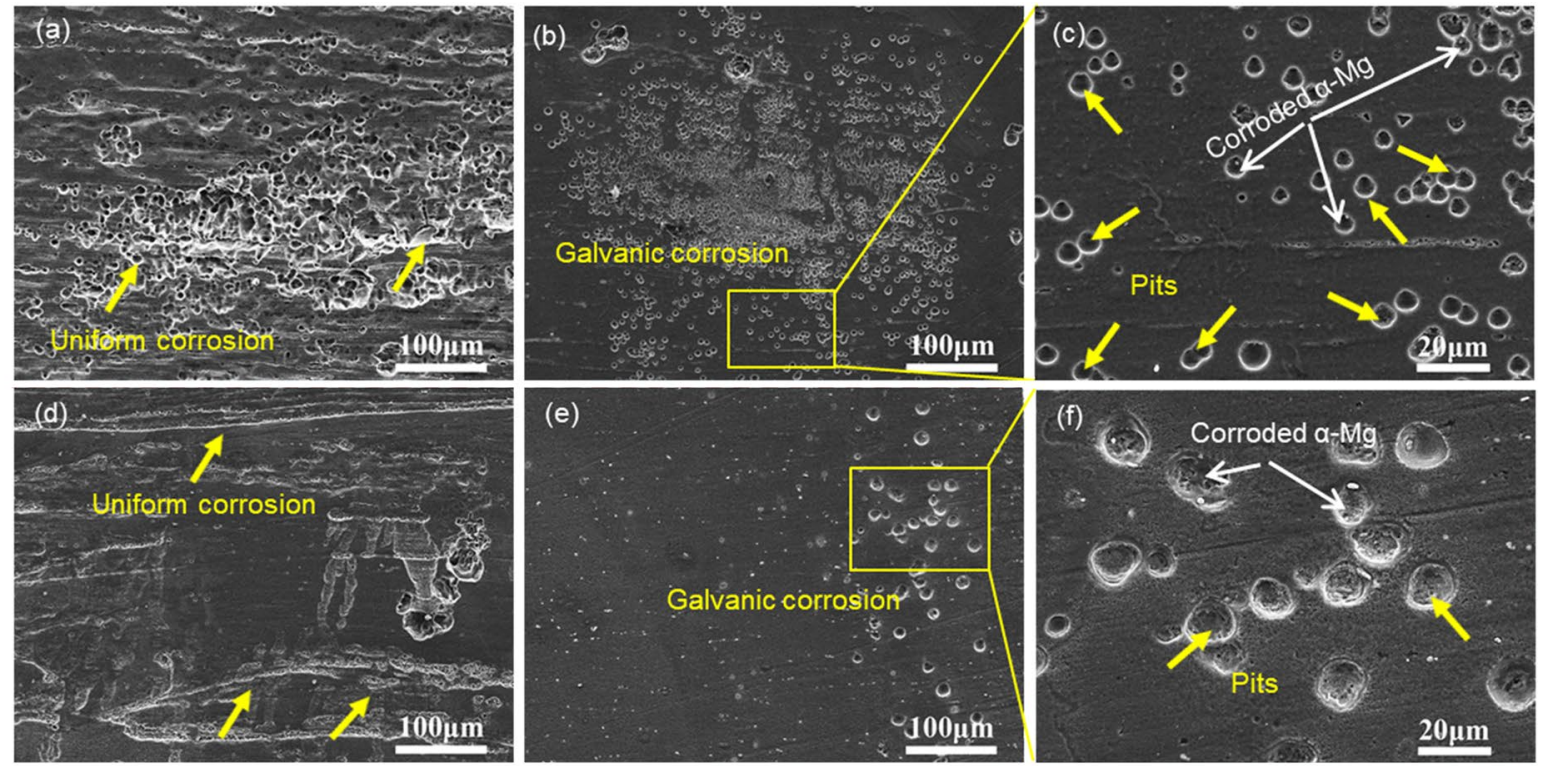

$280-0.01$
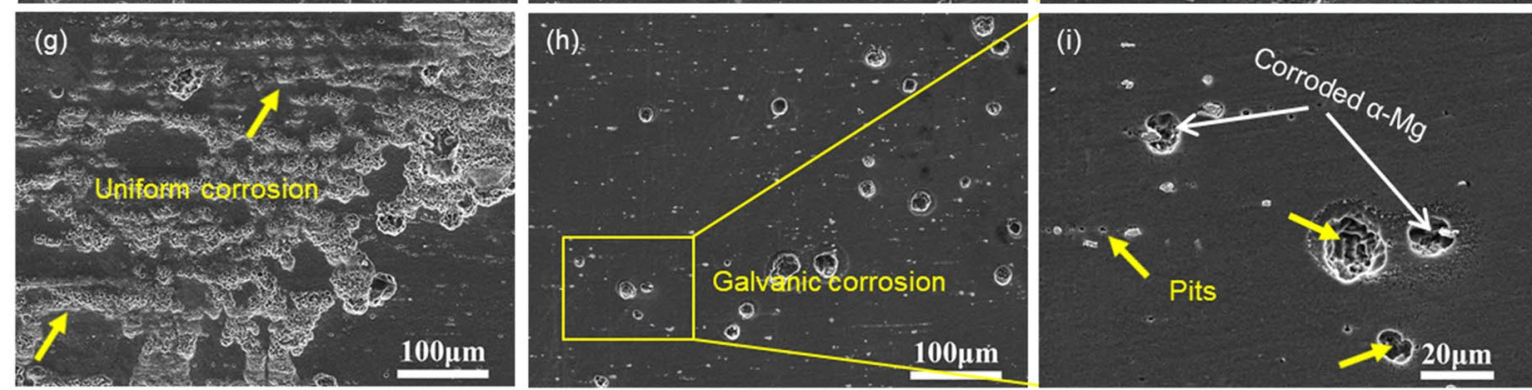

Fig. 11 Corrosion morphologies of as-extruded $\mathrm{Mg}-4 \mathrm{Zn}-2 \mathrm{Gd}-0.5 \mathrm{Ca}$ alloy immersed in $3.5 \mathrm{wt} \% \mathrm{NaCl}$ solution for $40 \mathrm{~min}$ : a-c $280{ }^{\circ} \mathrm{C}$, $0.1 \mathrm{~mm} / \mathrm{s} ; \mathbf{d}-\mathbf{f} 280{ }^{\circ} \mathrm{C}, 0.01 \mathrm{~mm} / \mathrm{s} ; \mathbf{g}-\mathbf{i} 360{ }^{\circ} \mathrm{C}, 0.01 \mathrm{~mm} / \mathrm{s}$ 

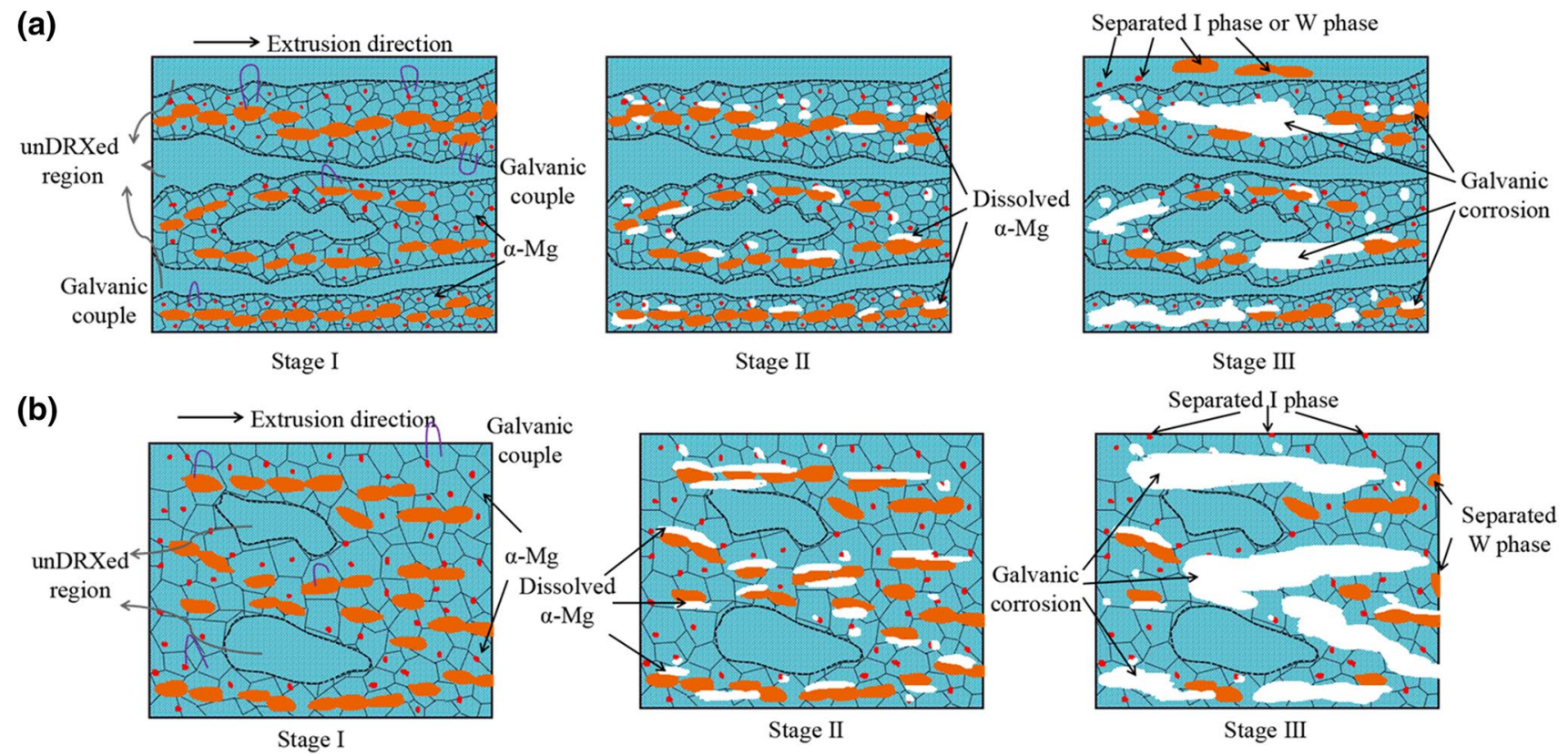

Fig. 12 Schematic illustrations of corrosion mechanism for the as-extruded $\mathrm{Mg}-4 \mathrm{Zn}-2 \mathrm{Gd}-0.5 \mathrm{Ca}$ alloy: a less DRXed region; b more DRXed region

unDRXed regions may have much more Gd content than the DRXed regions. According to Ref [41], the dissolution of rare earth elements can form a more stable protective film, which increases the difficulty of corrosion reaction to some extent and increases the corrosion resistance. Owing to above reasons, the corrosion resistance of unDRX regions is better than that of the DRXed region in present $\mathrm{Mg}-4 \mathrm{Zn}-2 \mathrm{Gd}-0.5 \mathrm{Ca}$ alloy.

To better reveal corrosion behavior about the as-extruded $\mathrm{Mg}-4 \mathrm{Zn}-2 \mathrm{Gd}-0.5 \mathrm{Ca}$ alloy, the schematic illustration is presented in Fig. 12. The corrosion mechanism concerning $\mathrm{Mg}-4 \mathrm{Zn}-2 \mathrm{Gd}-0.5 \mathrm{Ca}$ alloy containing a large amount of unDRXed regions is presented in Fig. 12a. In Stage I, the W and I phases are distributed in DRXed region, wherein the W phase is striped along the extrusion direction. The corrosion preferentially occurs in the DRXed region, and the galvanic couples are formed between phase and $\alpha-\mathrm{Mg}$ substrate. In stage II, the potential of $\alpha-\mathrm{Mg}$ substrate is lower than the phase, and the substrate acts as anode and the phase is cathode; galvanic corrosion occurs, and $\alpha-\mathrm{Mg}$ near the phase dissolves preferentially, as revealed by the black arrows. In stage III, more and more $\mathrm{Cl}^{-}$penetrates into the substrate and corrosion continues to propagate around the phase, and the area of corrosion increases gradually, resulting in the falling off of the $\mathrm{W}$ and I phases.

Accompanied with increasing extrusion rate and temperature, the degree of DRX in $\mathrm{Mg}-4 \mathrm{Zn}-2 \mathrm{Gd}-0.5 \mathrm{Ca}$ alloy increases obviously, and the corrosion behavior containing a large amount of DRXed regions is described in Fig. 12b.
Due to the existence of a great deal of precipitate, galvanic corrosion acts a dominant part in the procedure of corrosion.

\section{Conclusions}

1. With the decrease in extrusion speed, the $V_{\text {pre }}, V_{\mathrm{DRX}}$ and $d_{\mathrm{DRX}}$ of $\mathrm{Mg}-4 \mathrm{Zn}-2 \mathrm{Gd}-0.5 \mathrm{Ca}$ alloy decrease, and the corrosion rate also decreases. With the increase in extrusion temperature, the values of $V_{\text {pre }}, V_{\mathrm{DRX}}$ and $d_{\mathrm{DRX}}$ increase, and the corrosion resistance of the alloy decreases.

2. When the extrusion rate is $0.01 \mathrm{~mm} / \mathrm{s}$ and the extrusion temperature is $280^{\circ} \mathrm{C}$, the alloy has the best corrosion resistance, and the corrosion rate is $7.37 \mathrm{~mm} /$ year.

3. The main factors affecting the extruded $\mathrm{Mg}-4 \mathrm{Zn}-2 \mathrm{Gd}-$ $0.5 \mathrm{Ca}$ alloy are $V_{\mathrm{pre}}, V_{\mathrm{DRX}}$ and $d_{\mathrm{DRX}}$. The lower precipitated phase reduces the chance of galvanic corrosion between matrix and precipitated phase. Moreover, the decrease in $V_{\mathrm{DRX}}$ and $d_{\mathrm{DRX}}$ increases the basal texture of the alloy surface, which makes the corrosion slow and uniform.

4. The corrosion of extruded $\mathrm{Mg}-4 \mathrm{Zn}-2 \mathrm{Gd}-0.5 \mathrm{Ca}$ alloy occurs preferentially on the magnesium matrix around $\mathrm{W}$ and I phases in the DRXed zone. With the further corrosion, the corrosion continues to spread along the phase, and the corrosion area gradually increases. Galvanic corrosion plays a leading role in the corrosion process. 
Acknowledgements This work was financially supported by the National Natural Science Foundation of China (Nos. 51771128, 51771129 and 51201112), the Projects of International Cooperation in Shanxi (No. 201703D421039] and the Natural Science Foundation of Shanxi (No. 201601D011034).

\section{References}

[1] Q.X. Shi, C.J. Wang, K.K. Deng, K.B. Nie, M. Cao, W.M. Gan, W. Liang. Mater. Sci. Eng. A. 772, 138827 (2020)

[2] B.J. Wang, D.K. Xu, J. Sun, E.H. Han, Corros. Sci. 157, 347 (2019)

[3] P.P. Wu, K.K. Deng, K.B. Nie, Z.Z. Zhang, Acta Metall. Sin. (Engl. Lett.) 32, 218 (2019)

[4] K.K. Deng, C.J. Wang, K.B. Nie, X.J. Wang, Acta Metall. Sin. (Engl. Lett.) 32, 413 (2019)

[5] S. Koleini, M.H. Idris, H. Jafari, Mater. Des. 33, 20 (2012)

[6] K. Song, F.S. Pan, X.H. Chen, Z.H. Zhang, A.T. Tang, J. She, Z.W. Yu, H.C. Pan, X.Y. Xu, Mater. Lett. 157, 73 (2015)

[7] M. Liu, P. Schmutz, P.J. Uggowitzer, G. Song, A. Atrens, Corros. Sci. 52, 3687 (2010)

[8] H. Miao, H. Huang, Y. Shi, H. Zhang, J. Pei, G. Yuan, Corros. Sci. 122, 90 (2017)

[9] K.B. Nie, K.K. Deng, X.J. Wang, F.J. Xu, K. Wu, M.Y. Zheng, Mater. Sci. Eng. A 624, 157 (2015)

[10] F. Lu, A. Ma, J. Jiang, Y. Guo, D. Yang, D. Song, J. Chen, Corros. Sci. 94, 171 (2015)

[11] P.P. Wu, F.J. Xu, K.K. Deng, F.Y. Han, Z.Z. Zhang, R. Gao, Corros. Sci. 127, 280 (2017)

[12] D. Sachdeva, Corros. Sci. 60, 18 (2012)

[13] M. Yamasaki, N. Hayashi, S. Izumi, Y. Kawamura, Corros. Sci. 49, 255 (2007)

[14] R. Arrabal, E. Matykina, F. Viejo, P. Skeldon, G.E. Thompson, Corros. Sci. 50, 1744 (2008)

[15] T. Zhang, G. Meng, Y. Shao, Z. Cui, F. Wang, Corros. Sci. 53, $2934(2011)$

[16] S.Z. Khalajabadi, M.R. Abdul Kadir, S. Izman, M. Kasiri-Asgarani, Surf. Coat. Technol. 277, 30 (2015)

[17] S.Z. Khalajabadi, A.B.H. Abu, N. Ahmad, M.A.M. Yajid, N.B. Hj Redzuan, R. Nasiri, W. Haider, I. Noshadi, J. Mech. Behav. Biomed. Mater. 77, 360 (2018)

[18] S.Z. Khalajabadi, M.A.M. Yajid, A.B. Haji Abu, N. Ahmad, N. Redzuan, A.F. Ismail, S. Asadi, I. Noshadi, Mater. Chem. Phys. 214, 449 (2018)
[19] R.H. Buzolin, M. Mohedano, C.L. Mendis, B. Mingo, D. Tolnai, C. Blawert, K.U. Kainer, H. Pinto, N. Hort, Mater. Sci. Eng. A 682, 238 (2017)

[20] X. Zhang, Y. Wu, Y. Xue, Z. Wang, L. Yang, Mater. Lett. 86, 42 (2012)

[21] Y. Song, D. Shan, R. Chen, E.H. Han, Corros. Sci. 52, 1830 (2010)

[22] J.S. Zhang, D. Wang, W.B. Zhang, H.X. Pei, Z.Y. You, C.X. Xu, W.L. Cheng, Mater. Corros. 66, 542 (2015)

[23] X. Zhang, Z. Ba, Z. Wang, Y. Xue, Corros. Sci. 105, 68 (2016)

[24] S.W. Xu, M.Y. Zheng, S. Kamado, K. Wu, G.J. Wang, X.Y. Lv, Mater. Sci. Eng. A 528, 4055 (2011)

[25] D.H. Bae, S.H. Kim, D.H. Kim, W.T. Kim, Acta Mater. 50, 2343 (2002)

[26] R.C. Zeng, W.C. Qi, H.Z. Cui, F. Zhang, S.Q. Li, E.H. Han, Corros. Sci. 96, 23 (2015)

[27] S.S. Li, B. Tang, D.B. Zeng, J. Alloys Compd. 437, 317 (2007)

[28] K. Hirai, H. Somekawa, Y. Takigawa, K. Higashi, Mater. Sci. Eng. A 403, 276 (2005)

[29] X. Gu, Y. Zheng, Y. Cheng, S. Zhong, T. Xi, Biomaterials 30, 484 (2009)

[30] F. Cao, Z. Shi, G.L. Song, M. Liu, M.S. Dargusch, A. Atrens, Corros. Sci. 90, 176 (2015)

[31] W.J. Li, K.K. Deng, X. Zhang, K.B. Nie, F.J. Xu, Mater. Sci. Eng. A 677, 367 (2016)

[32] M. Ascencio, M. Pekguleryuz, S. Omanovic, Corros. Sci. 87, 489 (2014)

[33] D. Song, A. Ma, J. Jiang, P. Lin, D. Yang, J. Fan, Corros. Sci. 52, $481(2010)$

[34] Z. Szklarz, M. Bisztyga, H. Krawiec, L. Lityńska-Dobrzyńska, Ł. Rogal, Appl. Surf. Sci. 405, 529 (2017)

[35] P. Minárik, R. Král, M. Janeček, Appl. Surf. Sci. 281, 44 (2013)

[36] Y. Song, D. Shan, E.H. Han, J. Mater. Sci. Technol. 33, 954 (2017)

[37] F.F. Cao, K.K. Deng, K.B. Nie, J.W. Kang, H.Y. Niu, J. Alloys Compd. 770, 1208 (2019)

[38] J.F. Wang, W.Y. Jiang, Y. Ma, Y. Li, S. Huang, Mater. Chem. Phys. 203, 352 (2018)

[39] J.W. Kang, C.J. Wang, K.K. Deng, K.B. Nie, Y. Bai, W.J. Li, J. Alloys Compd. 720, 196 (2017)

[40] H. Jia, X. Feng, Y. Yang, J. Mater. Sci. Technol. 34, 1229 (2018)

[41] J. Zhang, X. Niu, X. Qiu, K. Liu, C. Nan, D. Tang, J. Meng, J. Alloys Compd. 471, 322 (2009) 